\title{
Investigation of ethane pyrolysis and oxidation at high pressures using global optimization based on shock tube data
}

\author{
Viktor Samu $^{1}$, Tamás Varga ${ }^{1,2}$, Tamás Turányi ${ }^{1}$ \\ ${ }^{1}$ Institute of Chemistry, Eötvös University (ELTE), Budapest, Hungary \\ ${ }^{2}$ MTA-ELTE Research Group on Complex Chemical Systems, Budapest, Hungary
}

\begin{abstract}
Tranter et al. conducted a series of experiments of ethane oxidation and pyrolysis covering a wide range of temperature $(800 \mathrm{~K}-1500 \mathrm{~K})$ and pressure $(5 \mathrm{bar}-1000 \mathrm{bar})$ in a high pressure shock tube. The oxidation and pyrolysis of ethane were carried out behind reflected shock waves, and the concentrations of the reaction products were measured by gas chromatography. The results of these experiments were re-evaluated by optimizing selected rate parameters of the NUIG C5 combustion mechanism. The rate coefficients of 14 reactions were selected based on sensitivity analysis and preliminary uncertainty estimations for optimization. Arrhenius parameters $(A, n, E)$ of the selected reaction steps were optimized using not only the experimental data of Tranter et al., but also the results of direct measurements related to these reactions. The obtained mechanism with the optimized rate parameters described the experiments of Tranter et al. much better than the original mechanism. New rate coefficient recommendations were obtained for all reactions with temperature dependent uncertainties including well studied reactions such as $\mathrm{C}_{2} \mathrm{H}_{6}+\mathrm{OH}=\mathrm{C}_{2} \mathrm{H}_{5}+\mathrm{H}_{2} \mathrm{O}$ and less-known reactions like $\mathrm{C}_{2} \mathrm{H}_{3}+\mathrm{O}_{2}=\mathrm{CH}_{2} \mathrm{CHO}+\mathrm{O}$.
\end{abstract}

\section{Introduction}

The pyrolysis and oxidation of ethane have been investigated by numerous research groups using various experimental techniques. The available measurements cover a wide range of temperature (600-2000 K) but have been carried out mostly below 10 bar pressures.

Tranter et al. [1-3] published several studies in which the pyrolysis and oxidation of ethane had been investigated using a high-pressure shock tube. Experiments were carried out in the temperature range of 829-1491 $\mathrm{K}$ and pressure range of 5-1000 bar, using pure ethane diluted with argon for the pyrolysis experiments, and stoichiometric and fuel $\operatorname{rich}(\varphi=5)$ ethane-oxygen mixtures diluted with argon for the oxidation experiments. In the experiments the concentrations of the stable products were measured behind the reflected shock wave using gas chromatography. The measured species were $\mathrm{C}_{2} \mathrm{H}_{6}$, $\mathrm{C}_{2} \mathrm{H}_{4}, \mathrm{C}_{2} \mathrm{H}_{2}, \mathrm{CH}_{4}, \mathrm{CH}_{2} \mathrm{O}, \mathrm{CO}, \mathrm{CO}_{2}$ and $\mathrm{O}_{2}$. The experimental conditions of the data that were utilized in the present work are summarized in Tables 1 and 2.

Simulations of the experiments were performed by Tranter et al. using the GRI 3.0 mechanism [4] and the mechanism of Miller et. al. [5] (which was referred to as the Miller 2001 mechanism). It was found that neither mechanism could reproduce their experimental data at all conditions. Some modifications were made [3] to the Miller 2001 mechanism in order to create a model that is able provide an overall good description of the experimental data, but this was not achieved. So far, a good overall reproduction has not been provided for the data of Tranter et al., and no clear mechanistic implications on the combustion of ethane, or recommendations for rate coefficient values were derived.
We have applied our recently developed optimization methodology [6] to create a mechanism that can provide a good description of all these experimental data and extract as much information as possible on the rate coefficients of the important reactions of high pressure ethane combustion.

According to our communications with the authors, the lowest pressure experiments at 5 and 15 bar could be considered the least dependable and were therefore omitted from our optimization.

\begin{tabular}{ccc}
\hline \multicolumn{3}{c}{ Pyrolysis experiments } \\
\hline$p /$ bar & $T / \mathrm{K}$ & Measured species \\
\hline 340 & $996-1400$ & $\mathrm{C}_{2} \mathrm{H}_{6}, \mathrm{C}_{2} \mathrm{H}_{4}, \mathrm{C}_{2} \mathrm{H}_{2}$ \\
613 & $1040-1401$ & $\mathrm{C}_{2} \mathrm{H}_{6}, \mathrm{C}_{2} \mathrm{H}_{4}, \mathrm{C}_{2} \mathrm{H}_{2}$ \\
1000 & $1186-1425$ & $\mathrm{C}_{2} \mathrm{H}_{6}, \mathrm{C}_{2} \mathrm{H}_{4}, \mathrm{C}_{2} \mathrm{H}_{2}, \mathrm{CH}_{4}$ \\
\hline
\end{tabular}

Table 1. Summary of the experimental conditions of the ethane pyrolysis experiments of Tranter et al.

\begin{tabular}{cccc}
\hline \multicolumn{4}{c}{ Oxidation experiments } \\
\hline$p /$ bar & $T / \mathrm{K}$ & $\varphi$ & Measured species \\
\hline 50 & $1103-1447$ & 5 & $\mathrm{C}_{2} \mathrm{H}_{6}, \mathrm{C}_{2} \mathrm{H}_{4}, \mathrm{C}_{2} \mathrm{H}_{2}, \mathrm{CO}$, \\
40 & $829-1383$ & 1 & $\mathrm{CO}_{2} \mathrm{H}_{6}, \mathrm{C}_{2} \mathrm{H}_{4}, \mathrm{C}_{2} \mathrm{H}_{2}, \mathrm{CO}$ \\
340 & $1056-1435$ & 1 & $\mathrm{C}_{2} \mathrm{H}_{6}, \mathrm{C}_{2} \mathrm{H}_{4}, \mathrm{C}_{2} \mathrm{H}_{2}, \mathrm{CO}$, \\
613 & $1083-1470$ & 1 & $\mathrm{CH}_{2} \mathrm{H}_{6}, \mathrm{C}_{2} \mathrm{H}_{4}, \mathrm{C}_{2} \mathrm{H}_{2}, \mathrm{CO}$ \\
1000 & $1157-1361$ & 1 & $\mathrm{C}_{2} \mathrm{H}_{6}, \mathrm{C}_{2} \mathrm{H}_{4}, \mathrm{C}_{2} \mathrm{H}_{2}, \mathrm{CO}$ \\
\hline
\end{tabular}

Table 2. Summary of the experimental conditions of the ethane oxidation experiments of Tranter et al. 


\section{Selection of a mechanism for optimization}

Our optimization methodology requires a starting mechanism that can qualitatively describe the experimental data that we wish to use as optimization targets. The NUIG C5 v49 hydrocarbon combustion mechanism [7] was developed for the combustion of hydrocarbons and validated against experiments carried out in a wide range of conditions. Therefore, it is a good candidate for a starting point of an optimization. The NUIG C5 mechanism has been recently modified using theoretical calculations of rate coefficients, the validating experiments were extended towards oxygenate combustion, and the improved mechanism was published as the Aramco Mech 1.3 [8]. The Aramco Mech 1.3 contains extensive usage of the PLOG formalism for describing the pressure dependence of rate coefficients, which provides an interpolation formula between rate coefficients expressed at given pressures. Unfortunately, many pressure dependent reactions, including potentially important ones in the Aramco Mech 1.3 do not contain 1000 bar within their interpolation range. While extrapolation could be possible at relatively short ranges, the upper limit of interpolation for some reactions is as low as 10 bar. For this reason the NUIG C5 mechanism was preferred over the Aramco Mech 1.3.

We have updated the NUIG C5 mechanism with our recently optimized hydrogen and syngas combustion mechanism [9].All $\mathrm{C}_{4}$ and $\mathrm{C}_{5}$ species, and their reactions were removed from the mechanism. Preliminary simulations indicated that updating the hydrogen and syngas combustion mechanism part had little effect on the reproduction of experimental data. The removal of the $\mathrm{C}_{4}$ and $\mathrm{C}_{5}$ molecules had less than $1 \%$ effect on all simulated concentration values. This updated version of the NUIG C5 mechanism was used as a basis of our further investigations.

\section{Selection of reactions for optimization}

The rate coefficients with the largest influence on the simulation results at the experimental conditions of Tranter et al. were identified using local sensitivity analysis of Arrhenius parameters $A$ of each reaction of the updated NUIG C5 mechanism, including the $A$ factors describing the low and high pressure limit rate coefficients for pressure dependent reactions. 14 reaction steps could be identified that could be determined with acceptable accuracy based on the experimental results of Tranter et al. These elementary reactions are listed in Table 3 . These reaction steps include four pressure dependent reactions and in each case the high pressure limit rate coefficients could be optimized. Apart from the 14 selected reactions, certain further reactions belonging to the hydrogen/syngas combustion system are also important for ethane combustion. The rate parameters of these reactions have already been optimized in our previous work [9]. The rate coefficients of these reactions were not modified here since the previous optimization was based on many experimental data where these reactions were important.

For the rate coefficients of the 14 selected reactions the prior uncertainty limits were determined. The uncertainty limits are characterized with uncertainty parameter $f$ which is defined by the following equation.

$$
f(T)=\log _{10}\left(\frac{k_{\max }}{k_{0}}\right)=\log _{10}\left(\frac{k_{0}}{k_{\text {min }}}\right)
$$

The method for the determination of the temperature dependent prior uncertainty domain of the Arrhenius parameters is described in detail by Nagy et al. [10] and only a short description is presented here.

For each elementary reaction investigated, all direct measurements and theoretical determinations of the rate coefficient were collected from the NIST Chemical Kinetics Database [11]. On an Arrhenius plot, the temperature dependence of $\log _{10} k$ outlines an uncertainty band of the rate coefficient. The distance of the $k^{\text {min }}$ and $k^{\text {max }}$ limits from the centerline defines the $f(T)$ temperature-dependent uncertainty parameter. The $f(T)$ points were converted to the prior covariance matrix of the Arrhenius parameters [12, 13]. The width of the uncertainty band was used for the determination of the limiting value of the acceptable rate coefficients during the optimization.

For reactions R98, R151, R153, R155 and R248 a temperature dependent uncertainty range could be determined. The $f(T)$ functions are plotted on Figure 1 for those cases where a temperature dependent uncertainty range could be determined, and a summary is also given in Table 3. For the other rate coefficients, only a small number of direct measurements or theoretical determinations were available, a statistically based temperature dependent uncertainty range could not be determined, and a temperature independent $f$ value was used.

Some direct measurements were also utilized as optimizations targets and are listed in Table 4. These experimental data were carefully selected from all available direct measurements.

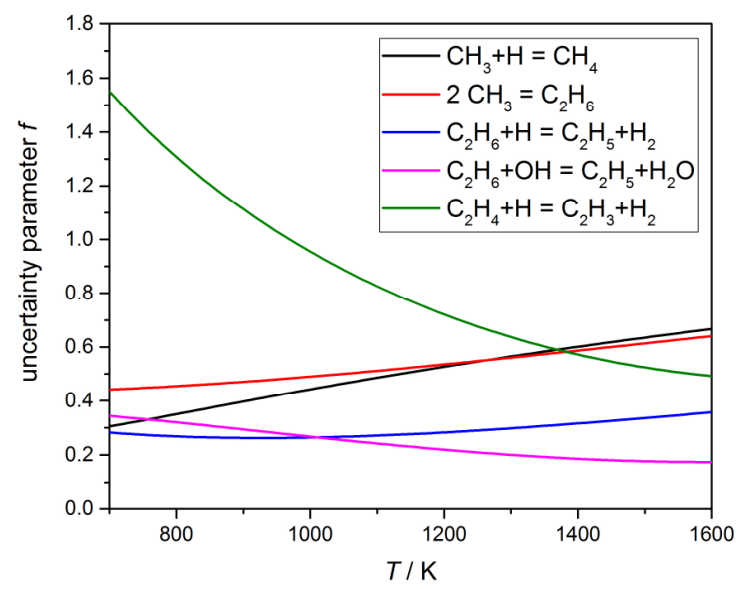

Figure 1. Temperature dependent prior uncertainty parameter $f$ in the temperature range of the experiments of Tranter et al. 


\section{Optimization method}

The global parameter optimization method applied here has been described in detail by Turányi et al. [6] and it has been used in several publications [14-16]. The optimal set of parameters was achieved by the minimization of the following objective function.

$$
Q(\mathbf{p})=\frac{1}{N} \sum_{i=1}^{N} \frac{1}{N_{i}} \sum_{j=1}^{N_{i}}\left(\frac{Y_{i j}^{\bmod }(\mathbf{p})-Y_{i j}^{\exp }}{\sigma\left(Y_{i j}^{\exp }\right)}\right)^{2}
$$

Here $N$ is the number of datasets and $N_{i}$ is the number of datapoints in the $i$-th dataset. Vector $\mathbf{p}$ contains the rate parameters selected for optimization. Values $y_{i j}^{\exp }$ and $\sigma\left(y_{i j}^{\exp }\right)$ are the $j$-th measured datapoint and its standard deviation, respectively, in the $i$-th dataset. The experimental standard deviation was determined for each dataset separately, based on their scatter. Constant absolute error $\left(\sigma\left(y_{i j}^{\text {exp }}\right)\right.$ is identical for all $j$ ) was assumed for the concentration measurements; in this case $Y_{i j}=y_{i j}$. Constant relative error $\left(\sigma\left(\ln y_{i j}^{\exp }\right)\right.$ is identical for all $j$ and $Y_{i j}=\ln y_{i j}$ ) was assumed for the rate coefficients determined in direct experiments. For the indirect measurement data, the simulated (modeled) value is $Y_{i j}^{\text {mod }}$, which is obtained from a simulation using an appropriate detailed mechanism. For the direct measurements, the modeled value $Y_{i j}^{\text {mod }}$ is calculated using the appropriate expression of the rate coefficient at a given temperature, pressure, and bath gas composition.

The details of the global optimization algorithm, and the method for estimating the covariance matrix of the optimized parameters and the uncertainties of the optimized rate coefficients have been described in detail in [6] and are not discussed here.

\section{Conclusions}

An optimized mechanism was obtained as a result of the parameter optimization procedure. The progress of the optimization can be characterized of the decrease of the objective function value $Q$. As a result of optimization the description of oxidation experiments improved to $Q=9.81$, starting from the initial value of $Q=37.50$. The corresponding values for the pyrolysis data and the direct measurements are 4.47/9.06 and $3.58 / 22.69$, respectively. Overall, the objective function value considering all experimental data decreased to $Q=7.04$ starting from $Q=27.33$.

The new mechanism describes overall better the experimental results of Tranter et al. than the original and updated NUIG C5 mechanisms, and also than the GRI 3.0 mechanism which was used by the authors of the experimental results for simulating their experiments. Figure 2 show some examples of the measured and calculated concentration profiles.

These figures demonstrate that some previously problematic areas, such as the description of the $\mathrm{C}_{2} \mathrm{H}_{2}$ profiles could be greatly improved while the performance at those areas that the other mechanisms worked well, such as the description of the $\mathrm{C}_{2} \mathrm{H}_{6}$ profiles remained good. Some issues remained for the 50 bar dataset, as Figure $2 \mathrm{~b}$. shows. A peak was measured in the concentrations of $\mathrm{C}_{2} \mathrm{H}_{2}, \mathrm{CO}$ and $\mathrm{CO}_{2}$ near $1400 \mathrm{~K}$, while all mechanisms tested here including the optimized model, predict that such a peak occurs at much higher temperatures. This indicated a possible systematic error in these species profiles as none of the investigated models could reproduce this peak, and the optimization procedure also could not solve this issue.

\begin{tabular}{llcccc}
\hline $\begin{array}{c}\text { Reaction } \\
\text { number }\end{array}$ & \multicolumn{1}{c}{ Reaction } & $\begin{array}{c}f \text { uncertainty } \\
\text { parameter }\end{array}$ & $\ln A$ & $n$ & $E / R$ \\
\hline R43 & $\mathrm{CH}_{2} \mathrm{O}+\mathrm{OH}=\mathrm{HCO}+\mathrm{H}_{2} \mathrm{O}$ & 0.35 & 27.75 & 0.423 & 366 \\
R98 HPL & $\mathrm{CH}_{3}+\mathrm{H}=\mathrm{CH}_{4}$ & $(0.31-0.67)^{*}$ & 21.35 & 1.482 & -1010 \\
R109 & $\mathrm{CH}_{3}+\mathrm{HO}_{2}=\mathrm{CH}_{3} \mathrm{O}+\mathrm{OH}$ & 1.00 & -0.14 & 3.495 & -3809 \\
R151 HPL & $2 \mathrm{CH}_{3}=\mathrm{C}_{2} \mathrm{H}_{6}$ & $(0.44-0.64)^{*}$ & 53.71 & -3.037 & 1841 \\
R152 HPL & $\mathrm{C}_{2} \mathrm{H}_{5}+\mathrm{H}=\mathrm{C}_{2} \mathrm{H}_{6}$ & 1.00 & 14.80 & 2.326 & -1575 \\
R153 & $\mathrm{C}_{2} \mathrm{H}_{6}+\mathrm{H}=\mathrm{C}_{2} \mathrm{H}_{5}+\mathrm{H}_{2}$ & $(0.28-0.36)^{*}$ & 15.69 & 2.091 & 2940 \\
R155 & $\mathrm{C}_{2} \mathrm{H}_{6}+\mathrm{OH}=\mathrm{C}_{2} \mathrm{H}_{5}+\mathrm{H}_{2} \mathrm{O}$ & $(0.34-0.17)^{*}$ & 9.53 & 2.842 & -53 \\
R157 & $\mathrm{C}_{2} \mathrm{H}_{6}+\mathrm{CH}=\mathrm{C}_{2} \mathrm{H}_{5}+\mathrm{CH}_{4}$ & 0.70 & 22.55 & 1.084 & 6112 \\
R158 & $\mathrm{C}_{2} \mathrm{H}_{6}+\mathrm{HO}=\mathrm{C}_{2} \mathrm{H}_{5}+\mathrm{H}_{2} \mathrm{O}_{2}$ & 1.00 & -11.96 & 5.392 & 6266 \\
R163 HPL & $\mathrm{C}_{2} \mathrm{H}_{4}+\mathrm{H}=\mathrm{C}_{2} \mathrm{H}_{5}$ & 0.50 & 40.33 & -1.086 & 2239 \\
R248 & $\mathrm{C}_{2} \mathrm{H}_{4}+\mathrm{H}=\mathrm{C}_{2} \mathrm{H}_{3}+\mathrm{H}_{2}$ & $(1.56-0.49)^{*}$ & -34.82 & 8.626 & 1049 \\
R251 & $\mathrm{C}_{2} \mathrm{H}_{4}+\mathrm{OH}=\mathrm{C}_{2} \mathrm{H}_{3}+\mathrm{H}_{2} \mathrm{O}$ & 0.70 & 4.68 & 3.378 & 286 \\
R266 & $\mathrm{C}_{2} \mathrm{H}_{3}+\mathrm{O}_{2}=\mathrm{CH}_{2} \mathrm{CHO}+\mathrm{O}$ & 1.00 & 42.38 & -1.419 & 3878 \\
R271 & $\mathrm{C}_{2} \mathrm{H}_{2}+\mathrm{O}_{2}=\mathrm{HCCO}_{+} \mathrm{OH}$ & 1.00 & 45.48 & -1.736 & 17534 \\
\hline
\end{tabular}

Table 3. List of the reactions selected for optimization, the prior uncertainty parameter values assigned to each reaction and the optimal rate parameters. Units are $\mathrm{cm}^{3} \mathrm{~mol} \mathrm{~s} \mathrm{~K}$. HPL stands for high pressure limit.

*See Figure 1. The values correspond to the temperature range of $700 \mathrm{~K}-1600 \mathrm{~K}$. 


\begin{tabular}{llcc}
\hline Reaction & Authors & Ref & T / K \\
\hline $\mathrm{CH}_{2} \mathrm{O}+\mathrm{OH}=\mathrm{H}_{2} \mathrm{O}+\mathrm{HCO}$ & Vasudevan et al. & {$[17]$} & $934-1670$ \\
$\mathrm{CH}_{3}+\mathrm{CH}_{3}+\mathrm{M}=\mathrm{C}_{2} \mathrm{H}_{6}+\mathrm{M}$ & Du et al. & {$[18]$} & $1175-1742$ \\
$\mathrm{CH}_{3}+\mathrm{CH}_{3}+\mathrm{M}=\mathrm{C}_{2} \mathrm{H}_{6}+\mathrm{M}$ & Hwang et al. & {$[19]$} & $1174-1649$ \\
$\mathrm{C}_{2} \mathrm{H}_{6}+\mathrm{H}=\mathrm{C}_{2} \mathrm{H}_{5}+\mathrm{H}_{2}$ & Bryukov et al. & {$[20]$} & $467-826$ \\
$\mathrm{C}_{2} \mathrm{H}_{6}+\mathrm{H}=\mathrm{C}_{2} \mathrm{H}_{5}+\mathrm{H}_{2}$ & Cao et al. & {$[21]$} & $876-1016$ \\
$\mathrm{C}_{2} \mathrm{H}_{4}+\mathrm{OH}=\mathrm{C}_{2} \mathrm{H}_{3}+\mathrm{H}_{2} \mathrm{O}$ & Tully & {$[22]$} & $651-900$ \\
$\mathrm{C}_{2} \mathrm{H}_{4}+\mathrm{OH}=\mathrm{C}_{2} \mathrm{H}_{3}+\mathrm{H}_{2} \mathrm{O}$ & Bhargava et al. & {$[23]$} & $1450-1743$ \\
$\mathrm{C}_{2} \mathrm{H}_{6}+\mathrm{OH}=\mathrm{C}_{2} \mathrm{H}_{5}+\mathrm{H}_{2} \mathrm{O}$ & Ancia et al. & {$[24]$} & $1527-1809$ \\
$\mathrm{C}_{2} \mathrm{H}_{6}+\mathrm{OH}=\mathrm{C}_{2} \mathrm{H}_{5}+\mathrm{H}_{2} \mathrm{O}$ & Tully et al. & {$[25]$} & $297-800$ \\
$\mathrm{C}_{2} \mathrm{H}_{6}+\mathrm{OH}=\mathrm{C}_{2} \mathrm{H}_{5}+\mathrm{H}_{2} \mathrm{O}$ & Krasnoperov et al. & {$[26]$} & $822-1367$ \\
\hline
\end{tabular}

Table 4. List of direct measurements used as optimization targets

a)

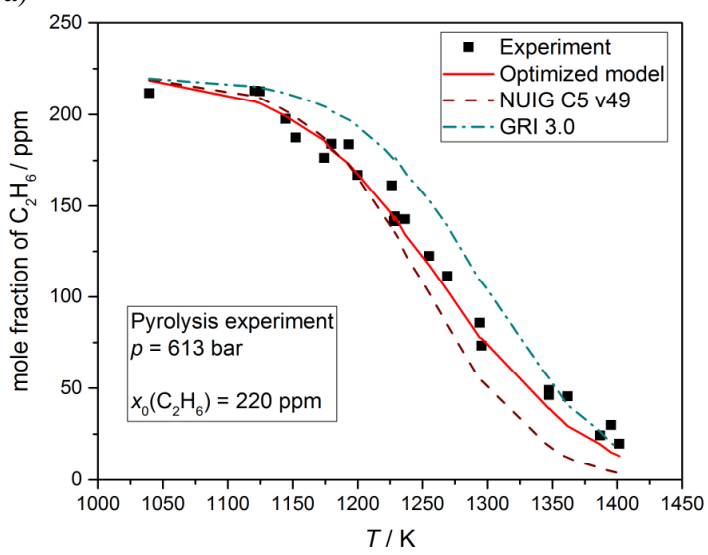

c)

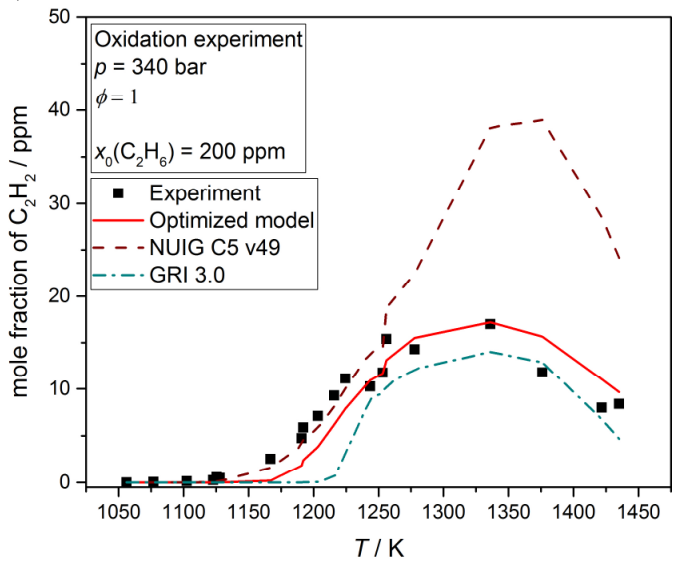

b)

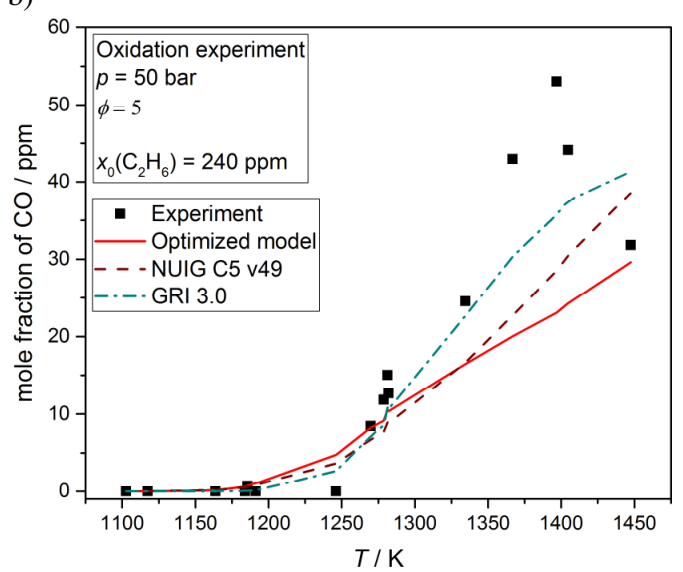

d)

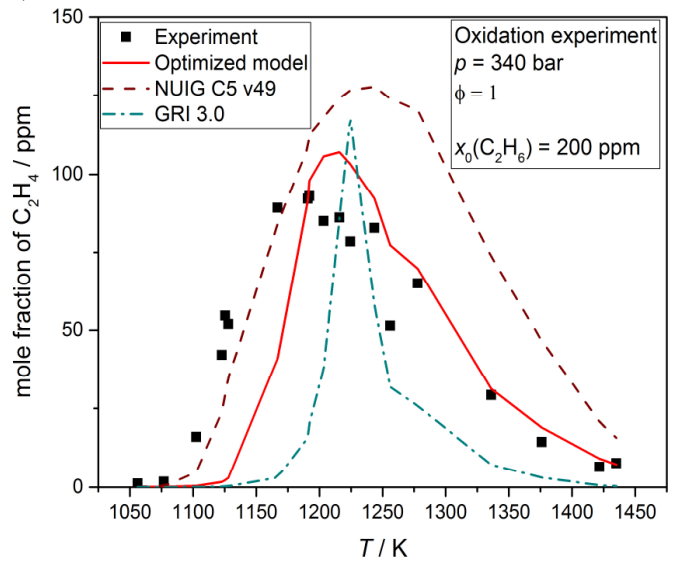

Figure 2. Experimental and simulated concentration profiles for various species at different conditions. The black squares denote the experimental results of Tranter et al. The simulation results of the optimized, the NUIG C5 v49, and the GRI 3.0 models are indicated by solid, dashed and dash-dotted lines, respectively. The experimental conditions are given on each figure. 
The optimized Arrhenius parameters are listed in Table 3. Figure 3 shows Arrhenius plots of the optimized rate coefficients with the determined posterior temperature dependent uncertainty ranges that were obtained from the joint covariance matrix of the optimized Arrhenius parameters. Most rate coefficients could be determined with good accuracy, but in most cases in relatively narrow temperature ranges. The reason is that the experiments of Tranter et al. cover a relatively narrow temperature range and information on the rate coefficients is provided only at the conditions where it is sensitive.

a)

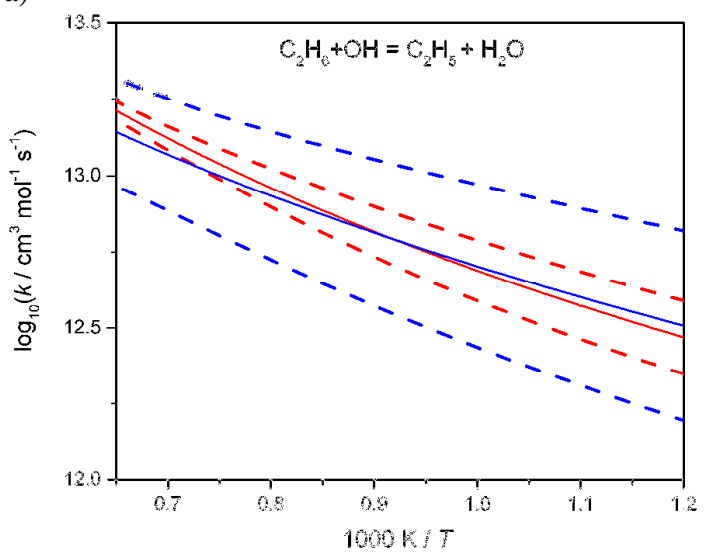

c)

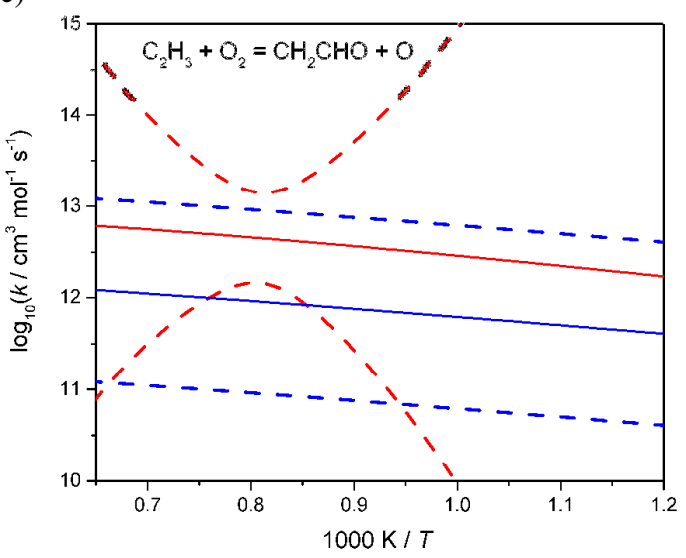

As an example, for reaction $\mathrm{C}_{2} \mathrm{H}_{3}+\mathrm{O}_{2}=\mathrm{CH}_{2} \mathrm{CHO}+\mathrm{O}$ (see Figure $3 \mathrm{c}$ ) the rate coefficient could be determined with acceptable uncertainty only in the very narrow temperature range of 1200-1300 K. A low uncertainty value was obtained at all temperatures for those reactions where direct measurements were used as optimization targets both above and below the temperature range of the experiments of Tranter et al., such as reaction $\mathrm{C}_{2} \mathrm{H}_{6}+\mathrm{OH}=\mathrm{C}_{2} \mathrm{H}_{5}+\mathrm{H}_{2} \mathrm{O}$ (see Figure 3a).

b)

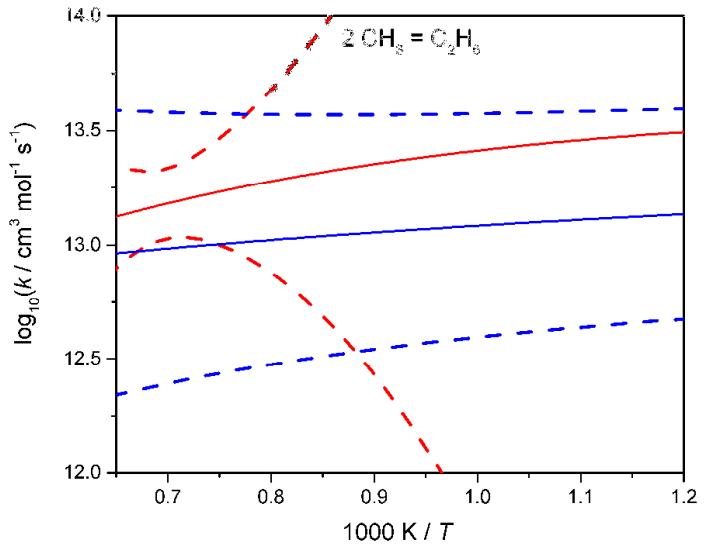

d)

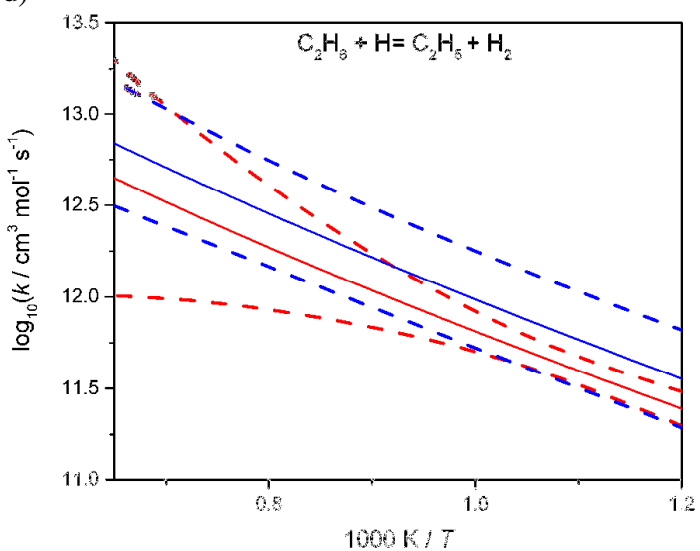

Figure 3. Arrhenius plots for the rate coefficients of reactions $\mathrm{C}_{2} \mathrm{H}_{6}+\mathrm{OH}=\mathrm{C}_{2} \mathrm{H}_{5}+\mathrm{H}_{2} \mathrm{O}$ (a), $2 \mathrm{CH}_{3}=\mathrm{C}_{2} \mathrm{H}_{6}$ (b), $\mathrm{C}_{2} \mathrm{H}_{3}+\mathrm{O}_{2}=\mathrm{CH}_{2} \mathrm{CHO}+\mathrm{O}$ (c) and $\mathrm{C}_{2} \mathrm{H}_{6}+\mathrm{H}=\mathrm{C}_{2} \mathrm{H}_{5}+\mathrm{H}_{2}$ (d). The blue lines indicate the initial mean rate coefficient expressions (solid) and the prior uncertainty limits (dashed). The red lines show the optimized rate coefficient expressions (solid) and the posterior uncertainty limits (dashed).

All uncertainty limits correspond to $3 \sigma\left(\log _{10} k\right)$. 


\section{Acknowledgements}

The authors thank Prof. Ken Brezinsky and Dr. Aleksandr Fridlyand (Department of Mechanical and Industrial Engineering, University of Illinois at Chicago, USA) for sending us the raw experimental data related to articles [1-3]. The Hungarian Scientific Research Fund OTKA (ERA Chemistry grant NN100523) provided financial support. The helpful discussions with Ms. Éva Valkó and Mr. Carsten Olm are also gratefully acknowledged.

\section{References}

1. R. S. Tranter; H. Ramamoorthy; A. Raman; K. Brezinsky; M. D. Allendorf, Proc. Combust. Inst. 29 (2002) 1267-1276

$2 . \quad$ R. S. Tranter; R. Sivaramakrishnan; K. Brezinsky; M. D. Allendorf, Phys. Chem. Chem. Phys. 4 (2002) 2001-2010

$3 . \quad$ R. S. Tranter; A. Raman; R. Sivaramakrishnan; K. Brezinsky, Int. J. Chem. Kinet. 37 (2005) 306-331

4. G. P. Smith; D. M. Golden; M. Frenklach; N. W. Moriary; B. Eiteneer; M. Goldenberg; C. T.

Bowman; R. K. Hanson; S. Song; W. C. Gardiner; V. V. Lissianski; Z. Qin GRI-Mech 3.0.

http://www.me.berkeley.edu/gri_mech/

$5 . \quad$ J. A. Miller; S. J. Klippenstein; S. H.

Robertson, Proc. Combust. Inst. 28 (2000) 1479-1486

$6 . \quad$ T. Turányi; T. Nagy; I. G. Zsély; M. Cserháti; T. Varga; B. T. Szabó; I. Sedyó; P. T. Kiss; A.

Zempléni; H. J. Curran, Int. J. Chem. Kinet. 44 (2012) 284-302

$7 . \quad$ D. Healy; D. M. Kalitan; C. J. Aul; E. L. Petersen; G. Bourque; H. J. Curran, Energ. Fuel 24 (2010) 1521-1528

$8 . \quad$ W. K. Metcalfe; S. M. Burke; S. S. Ahmed; H. J. Curran, Int. J. Chem. Kinet. 45 (2013) 638-675

9. T. Varga; C. Olm; I. G. Zsély; É. Valkó; H. J. Curran; T. Turányi, $35^{\text {th }}$ International Symposium on Combustion (2014) WiP Poster W3P093

10. T. Nagy; É. Valkó; I. Sedyó; I. G. Zsély; M. J. Pilling; T. Turányi, Combust. Flame (2015) in press DOI: 10.1016/j.combustflame.2015.01.005

11. J. A. Manion; R. E. Huie; R. D. Levin; D. R. Burgess Jr; V. L. Orkin; W. Tsang; W. S. McGivern; J. W. Hudgens; V. D. Knyazev; D. B. Atkinson; E. Chai; A. M. Tereza; C.-Y. Lin; T. C. Allison; W. G. Mallard; F. Westlet; J. T. Herron; R. F. Hampson; D. H. Frizzell NIST Chemical Kinetics Database, NIST Standard Reference Database 17, Version 7.0 (Web Version), Release 1.4.3, Data version 2008.12, National Institute of Standards and Technology, Gaithersburg, Maryland, 20899-8320. http://kinetics.nist.gov/ (08/01/2010),

12. T. Nagy; T. Turányi, Int. J. Chem. Kinet. 43 (2011) 359-378

13. T. Nagy; T. Turanyi, Reliab. Eng. Syst. Safe. 107 (2012) 29-34

14. T. Varga; I. G. Zsély; T. Turányi; T. Bentz; M. Olzmann, Int. J. Chem. Kinet. 46 (2014) 295-304
15. I. G. Zsély; T. Varga; T. Nagy; M. Cserháti; T. Turányi; S. Peukert; M. Braun-Unkhoff; C. Naumann; U. Riedel, Energy 43 (2012) 85-93

16. T. Varga; T. Nagy; C. Olm; I. G. Zsély; R. Pálvölgyi; É. Valkó; G. Vincze; M. Cserháti; H. J. Curran; T. Turányi, Proc. Combust. Inst. 35 (2015) 589-596

17. V. Vasudevan; D. F. Davidson; R. K. Hanson, Int. J. Chem. Kinet. 37 (2005) 98-109

18. H. Du; J. P. Hessler; P. J. Ogren, J. Phys. Chem. 100 (1996) 974-983

19. S. M. Hwang; H. G. G. Wagner; T. Wolff, Proc. Combust. Inst. 23 (1991) 90-105

20. M. G. Bryukov; I. R. Slagle; V. D. Knyazev, J. Phys. Chem. A 105 (2001) 6900-6909

21. J. R. Cao; M. H. Back, Canadian Journal of Chemistry-Revue Canadienne De Chimie 62 (1984) 8691

22. F. P. Tully, Chem. Phys. Lett. 143 (1988) 510-

514

23. A. Bhargava; P. R. Westmoreland, Combust. Flame 113 (1998) 333-347

24. R. Ancia; J. Vandooren; P. J. Van Tiggelen, Proc. Combust. Inst. 26 (1996)

25. F. P. Tully; A. R. Ravishankara; K. Carr, Int. J. Chem. Kinet. 15 (1983) 1111-1118

$26 . \quad$ L. N. Krasnoperov; J. V. Michael, J. Phys. Chem. A 108 (2004) 5643-5648 